Удк 005.2-043.86: 35.07 1(477)

О. В. Ніколюк,

д. е.н., профресор, професор кафедри менеджменту $і$ логістики,

Одеська начіональна академія харчових технологій

ORCID ID: 0000-0002-1665-0361

Ю. В. Авяченко,

к.е.н., дочент, дочент кафедри менеджменту $і$ логістики,

Одеська начіональна академія харчових технологій

ORCID ID: 0000-0002-8754-3256

T. В. Савченко,

к. е.н., дочент, дочент кафедри управління бізнесом,

Одесъка начіональна академія харчових технологіи

ORCID ID: 0000-0001-7990-1570

DOI: 10.32702/2306-6814.2021.6.98

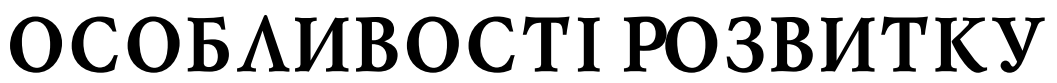 IBEHT-MEHEAЖMEHTУ В УКРАÏHI
}

\author{
O. Nikoliuk, \\ Doctor of Economic Sciences, Professor, Professor of the Department \\ of Management and Logistics, Odessa National Academy of Food Technologies \\ Y. Diachenk, \\ $\mathrm{PhD}$ in Economics, Associate Professor, Associate Professor of the Department \\ of Management and Logistics, Odessa National Academy of Food Technologies \\ T. Savchenko, \\ $\mathrm{PhD}$ in Economics, Associate Professor, Associate Professor of the Department \\ of business management, Odessa National Academy of Food Technologies
}

\section{FEATURES OF EVENT MANAGEMENT DEVELOPMENT IN UKRAINE}

Устатті представлено особливості розвитку івент-менеджментув Україні. Сучасна івент-індустрія в Україні досить динамічно розвивається і потребує залучення висококваліфікованих управлінських фахівців. Встановлено, що ринок івент-послуг в Україні, який почав активно розвиватися із 2005 р. суттєво змінився не тільки кількісно, а й якісно, що проявляється у такому: підвищилася якість наданих бізнесом послуг; розширився спектр послуг; застосування гнучкої цінової політики компаній; доступність ціни більшості із них. Систематизовані проблеми, які стримують розвиток івент-менеджменту та безпосередньо івент-ринку України, а саме: неготовність українських клієнтів до креативних рішень; відсутність на ринку платформи для комунікації стейкхолдерів; нестача кваліфікованих кадрів на такомуринку. Особливістю використання івент-менеджменту як одного із дієвих інструментів PR-менеджменту, $\epsilon$ те, що він орієнтований на отримання не одноразового ефекту, а сталого довгострокового процесущодо формування іміджу бізнесу, товару тощо, його впливу на суспільні інтереси і потреби. Доведено, що івент-менеджмент сприймається безпосередньо в двох контекстах: як бізнес та як дієвий інструмент маркетингових комунікацій. Зміст такого явища полягає у тому, щоб подати конкретному споживачеві товари та послуги, як презент. Встановлено, що івент-менеджмент як певний соціальний феномен є більш значимим управлінським та, у більшості маніпулятивним потенціалом, безпосередньо в аспекті критичної й творчої селекції для різних компонентів дотримання соціального досвіду, ніж безпосередньо звичайна рекламна діяльність або ж традиційний маркетинг. 
Сучасні тенденції розвитку такого напряму соціально-економічної діяльності як івент-менеджмент знаходять своє безпосереднє представлення і в практиці діяльності органів публічної влади. Така діяльність допомагає також розв 'язати проблеми соціального характеру, які вирішувати лише адміністративними методами на сьогодні неможливо - організація подій соціального значення, проведення соціальних акцій, підтримка волонтерських ініціатив тощо. Івентзаходи також підвищують лояльність населення до органів влади.

The article presents the peculiarities of event management development in Ukraine. It is established that the market of event services in Ukraine, which began to develop actively since 2005, has changed significantly not only quantitatively but also qualitatively, which is manifested in the following: the quality of services provided by business has increased; the range of services has expanded; application of flexible pricing policy of companies; affordability of most of them. Systematized problems that hinder the development of event management and directly the event market of Ukraine, namely: unpreparedness of Ukrainian clients for creative solutions; lack of a platform for stakeholder communication on the market; lack of qualified personnel in such a market. The peculiarity of using event management as one of the effective tools of PR management is that it is focused on obtaining not a one-time effect, but a sustainable long-term process of forming the image of business, product, etc., its impact on public interests and needs. It is proved that event management is perceived directly in two contexts: as a business and as an effective tool of marketing communications. The essence of this phenomenon is to provide a particular consumer with goods and services as a gift. It has been established that event management as a certain social phenomenon is more significant managerial and, in most cases, manipulative potential, directly in the aspect of critical and creative selection for various components of social experience than, directly, ordinary advertising or traditional marketing. Under event management, leading scientists propose to consider one of the branches of the service sector, which at this stage of development of the management system is developing at a very rapid pace around the world. That is, every year a significant number of companies turn to the provisions of event management as one of the effective tools for forming views on the company and its product.

Modern tendencies of development such direction of social and economic activity as event management find the direct representation in practice of public authorities activity. This activity also helps to solve social problems that can't be solved by administrative methods today - organizing events of social significance, holding social events, supporting volunteer initiatives, etc. Event measures also increase the loyalty of the population to the public authorities.

Ключові слова: іВент-менеджмент, іВент-технології, заходи, публічне управління, бізнес.

Key words: event management, event technologies, events, public administration, business.

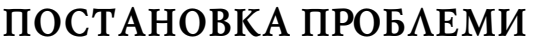

В умовах розвитку інформаційного суспільства особливої актуальності набувають питання розвитку івент-менеджменту, якийє викликом сучасності. Сучасна івент-індустрія в Україні досить динамічно розвивається і потребує залучення висококваліфікованих управлінських фрахівців. Так, позитивний досвід британських науковців щодо впровадження івент-менеджменту $є$ одним із найбільш популярних у світі та потребує представлення в українському науковому середовищі. Під івент-менеджментом провідні науковці пропонують розглядати одну із галузей сфрери послуг, яка на цьому етапі розвитку системи управління розвивається досить шаленими темпами у всьому світі. Тобто із кожним роком значна кількість компаній звертаються до положень івент-менеджменту як одного із ефективних інструментів формування поглядів до компанії і її продукту.

\section{АНА $\Lambda$ I ОСТАНHIX АОС $\Lambda$ IАЖЕНЬ І ПУБАІКАЦІЙ}

Дослідженням питань, пов'язаних із розвитком та реалізацією івент-менеджменту, займалися такі вітчизняні й зарубіжні науковці: Н. Пономарьова, Г. Тульчинский, А. Романцов, П. Шагайда, Ю. Бичун, Т. Лохина, А. Костін, Е. Попов, Е Патрушева, В. Баранчеєв, А. Шон, Б. Перрі, Дж. Там, П. Нортон, Дж. Нева у ін. у свою чергу винесені на обговорення питання $€$ недостатньо вивченими, у зв'язку із чим потребують додаткових наукових досліджень Водночас загрозливі тенденції, які сьогодні склалися в системі управління, свідчать про недостатню результативність менеджменту, що вимагає здійснення подальших наукових розвідок.

\section{META CTATTI}

Мета статті полягає в обгрунтуванні науково-прикладних засад розвитку івент-менеджменту в Україні. 


\section{ВИК ААА ОСНОВНОГО МАТЕРІААУ АОС АIАЖЕННЯ}

Івент у перекладі із англійської мови дослівно перекладається як певна розважальна або ж рекламна вистава, яка відбувається на театральній сцені, кіно-ж або телеекрані, на спортивній або ж цирковій арені із використанням різноманітних образотворчих прийомів, спеціальних ефектів, комп'ютерної графріки тощо. Поняття івент включає також у себе не тільки подію, захід, певну церемонію або ж шоу, а насамперед містить чіткі смислові відтінки для сприятливого впливу, виняткової події, отримання найбільш бажаного результату проведеного заходу. Такий підхід покликаний створити захід, який би насамперед сприймався його учасниками як специфічна, абсолютно виняткова, невним чином неповторна подія.

Тобто івент $є$ запланованою соціально-суспільною подією (заходом), який відбувається в певний час із певною метою і має чіткий резонанс для всього суспільства. Івент-менеджмент розглядається як прикладна галузь дослідження та простір для професійної практики, у сфері планування, проведенню і управлінню спеціальними заходами. Враховуючи вищевикладене, в основі будь-якого івент-менеджменту є подія, комплекс спеціальних заходів, організованих для організації просування товару або ж певної послуги. Спеціальна подія зі сторони бізнесу - це специфрічна форма залучення людини до інноваційної культури бренду, до відповідної корпоративної або ж іншої спільноти у контексті організації певних дій, можливих переживань. Тобто, запланована подія (івент) $є$ насамперед просторово-часовим феноменом, кожен із яких $є$ унікальним як результат злагодженої взаємодії публіки, навколишнього оточення, системи управління, враховуючи розробку окремих елементів й програми.

Перспективність впровадження івент-технологій полягає насамперед у тому, що вони завжди є різними, ніколи не повторюються. Кожен із них створюється із певною конкретною цільовою метою, а тому вам варто побувати там, у конкретному місці в певний час, задля отримання виняткових вражень. Саме сучасні івент-заходи $€$ дуже важливими, вони виконують сукупність стратегічних завдань та зазвичай досить ризиковано залишати їх організацію й проведення поза увагою або ж довіряти непрофресіоналам. Таким чином, івент-менеджмент включає досить широкий спектр маркетингових комунікацій, які реалізуються шляхом організації різних заходів. Обсяги впливу можуть також бути різними від одного підприємства до досить великих громадських мас. Ключовими рушійними силами для сприяння розвитку івент-менеджменту є результати проведення заходу й повернення вкладених у цей захід кошти. Такий вид діяльності включає дослідження особливостей бренду, представлення цільової аудиторії такого заходу, розробка концепції реалізації заходу, планування логістики та координування технічних аспектів щодо організації й проведення заходів. Таким чином, івентменеджмент $\epsilon$ довгостроковою програмою управління цим заходом. Особливістю використання івент-менеджменту як одного із дієвих інструментів PR менеджменту $€$ те, що він орієнтований на отримання не одноразового ефекту, а сталого довгострокового процесу щодо формування іміджу бізнесу, товару тощо, його впливу на суспільні інтереси і потреби.

Івент-менеджмент означає трансорормацію заходу у щось досить виняткове, неповторне із погляду конкретного споживача. Як окрема галузь національного господарства івент-індустрія сорормувалась на початку XX ст. У США 150 років тому івент-менеджмент отримав свій початок та розвиток. На сучасному етапі функціонування суспільства там вже існують професійні асоціації, необхідна методична література, представлені стандарти розвитку такої галузі. Івент-менеджмент $\epsilon$ досить потужною галуззю у сфері послуг, про що свідчать занчні прибутки компаній, які працюють у такій сорері. Так, у США сьогодні прибуток від функціонування івент-індустрії перевищує прибуток наприклад від автопримисловості [1]. Найбільшою популярністю у США користуються такі послуги івент-індустрії як планування заходів та їх координація, генерування ідеї, маркетинг та промоушн заходу, проведення дослідження й оцінка заходу.

У країнах Західної Європи івент-менеджмент $є$ відносно новим типом бізнесу (йому практично 25 років), а тому він ще не набув таких глобальних масштабів, як, наприклад, у США. Однак у більшості університетах створено курси й напрями із підготовки фахівців даної сорери. Відповідно в Україні івент-менеджмент - $є$ абсолютно новим напрямом. У нашій державі ринок івентпослуг практично став розвиватись лише із 2005 року. Таким чином, за період свого становлення ринок суттєво змінився не тільки кількісно, але й якісно насамперед підвищилась якість послуг, значно розширився спектр послуг, використовується досить гнучка цінова політика компаній, самі заходи практично починають набувати європейського рівня. Такожє й деякі труднощі. Як зазначають науковці, український ринок івент-технологій має високий рівень конкуренції, однак досить низьку культуру. Серед ключових проблем розвитку івент-менеджменту в Україні доцільно віднести: відсутність на ринку платорорми для налагодження комунікації стейкхолдерів, неготовність вітчизняних клієнтів до прийняття креативних рішень, недостатня кількість висококваліфрікованих фрахівцій [2]. Тобто ефективний івент-менеджмент $є$ перспективною для України галуззю економіки, яку варто розвивати.

Таким чином, ринок івент-послуг в Україні, який почав активно розвиватися із 2005 р. суттєво змінився не тільки кількісно, а й якісно, що проявляється у такому: підвищилася якість наданих бізнесом послуг; розширився спектр послуг; застосування гнучкої цінової політики компаній; доступність ціни більшості із них. Варто зауважити, що $є$ також й проблеми, які стримуютьрозвиток івент-менеджменту та безпосередньо івент-ринку України, а саме: неготовність українських клієнтів до креативних рішень; відсутність на ринку платформи для комунікації стейкхолдерів; нестача кваліфікованих кадрів на такому ринку.

Сьогодні наринку України функціонує більше 500 івенткомпаній, кожна із яких проводить практично по 30 заходів на рік. Загальний обсяг вітчизняного ринку, який використовує івент-менеджмент, складає практично 20 млн доларів (у свою чергу до фрінансово-політичної кризи - 30 млн доларів). Зростання конкуренції в ак- 
тивний період розгортання фрінансової кризи також спровокував вітчизняний бізнес, який спеціалізується на організації івент-заходів, до певного позиціонування себе на такому ринку, а саме до динамічного росту спеціалізації, чого раніше не спостерігалося. Значно підвищилася у діяльності профільних підприємств та роль Інтернету, медіа-каналів, таких як блоги, соціальні мережі, 150 років тому й інші різні Інтернет-співтовариства. Усе це $є$ результатом того, що організація спеціальних заходів на сьогодні $є$ невід'ємним складником управління відповідним іміджем, який є необхідний не лише для компаній або фірм, а й для України загалом [3].

Сучасні тенденції щодо розвитку такого напряму соціально-економічної діяльності знаходять своє представлення і в практиці діяльності безпосередньо органів публічної влади. Умови, які визначають можливості використання елементів івент-менеджменту в діяльності органів публічного управління, доцільно представити у таких аспектах.

По-перше, галопуюча диференціація населення, яка приходить на зміну сталому споживанню масового продукту. Відбувається демасифікація, що представляє собою розподіл всього населення на досить незначні групи, які відрізняються одна від одної за визначеними різноманітними характеристиками. Таким чином, результати демасифікації представляються всюди та у всьому. Варто лише подивитися, як багато виникло телеканалів та різних радіостанцій, які догоджають всім можливим споживацьким, культурним і навіть політичним смакам для різних верств населення. Також період "розваг для всіх" поступово уходять у минуле, поступаючись місцем абсолютно іншим видам, спеціально підібраним для окремого сегменту суспільства.

По-друге, саме у публічній сфері управління на сьогодні актуальності набуває питання домінування орієнтирів на споживача як повноправного учасника таких відносин, який регулюється не лише нормами права, але й відповідними законами попиту й пропозиції. Тобто перемагає той, хто, безпосередньо враховує цінності і смаки споживача, та, виходячи з них, будує свою цільову маркетингову політику. Таким чином, у контексті публічного управління це насамперед означає, що парадигма так званого "доброго урядування", яка досить активно реалізується у різних сучасних практиках державного управління саме розвинених країн, передбачає врахування учасника владних відносин.

По-третє, актуальності набуває поширення розвитку соціального маркетингу. Звичайна традиція пов'язувати наприклад назву компанії, продукту абож бренду із різними соціально-значущими явищами отримала активне поширення в останнє десятиліття та, за отриманими прогнозами експертів, вона також продовжить набирати обертів у перспективі. Виник, як інструмент поточного просування товару, соціальний маркетинг, що еволюціонував до довгострокової ринкової стратегії, яка певним чином визначає позиціонування продукту. Тобто, використовуючи соціальний маркетинг, відповідні компанії отримують рідкісну можливість фрормування довготривалих й міцних взаємин із споживачами.

Головна перевага такої стратегії полягає у тому, що продукція пов' язується із соціальним явищем, є актуаль- ною для цільової групи клієнтів та одержує, таким чином, відповідні конкурентні переваги. Врахування ціннісних орієнтирів та турбот цільової групи суттєво зміцнює взаємозалежність кожного споживача, бренд і заходи. Це також певним чином може сприяти й врегулюванню завдань публічного управління.

Тобто для сфрери публічної влади також актуалізуються проблеми соціального характеру, які вирішувати лише адміністративними методами на сьогодні $€$ просто неможливим. Використання підходів впровадження маркетингового менеджменту, особливо у напрямку організації подій соціального значення, проведення соціальних акцій, підтримка волонтерських ініціатив безпосередньо мають будуватися на сучасних методах івент-менеджменту.

По-четверте, відбувається зростання попиту на різні локальні покрокові заходи. Тобто, розробивши глобальну маркетингову стратегію, бізнес зазвичай виявляє, що найскладнішим завданням стає формування ії зрозумілою для певних людей на місцевому рівні. Саме у нашій країні дуже низькі індикатори довіри та лояльності споживача до вітчизняного виробника. Схожа ситуація і з публічною владою, що актуалізує проблему підвищення авторитету саме публічних органів влади, й може вирішуватись шляхом імплементації стратегій івент-менеджменту [4].

Таким чином, широкомасштабні національні соціальні рекламні організації приносять мінімальний результат, ніж досить вузькопрофільні соціальні акції для публічної влади на локальному рівні. Тобто локальний івент-менеджмент, наприклад, органів місцевого самоврядування, дозволяє "достукатися" до кожного окремого городянина, будуючи досить міцний асоціативний зв'язок безпосередньо між його цінностями та результатами діяльності для місцевої влади. Так, локальні маркетингові програми обов'язково повинні бути інтегровані в глобальну стратегію просування, приміром адміністративних послуг, для того, щоб забезпечити їх результативність та сталість [5-6].

По-п'яте, розважальність. Під час реалізації івентзаходів завжди присутній елемент розваги, навіть у заходах публічної влади. Адже на сучасному ринку, перенасиченому пропозицією, та інфрормацією, така проста цінність, як розвага, може відігравати вирішальну роль у встановленні комунікації безпосередньо між владою і населенням. Розваги виявилися самим популярним товаром саме глобального значення. Отже, розважальність - це тенденція до того, щоб представлений елемент розваги був присутній у маркетинговій активності, у тому числі й активності органів публічного управління.

По-шосте, збільшення рівня залучення аудиторії до спеціальних подій. Перевага подієвого менеджменту у публічній сорері полягає в тому, що аудиторії надається той досвід, який неможливо отримати, спостерігаючи за подією на екрані, слухаючи радіо або читаючи газету. Це означає, що захід з початку до кінця має бути таким, щоб кожен відвідувач міг отримати задоволення, релаксувати під час проведення заходу. Це сприяє значною мірою активізації громадян для участі у вирішенні спільних суспільних завдань та управлінні державою. 
Соціально-економічними передумовами використання івент-менеджменту в сучасній соціальній системі й можливості його імплементації у публічну сферу. Івентменеджмент - це, із однієї сторони, вид інтегрованих маркетингових комунікацій, який представляє собою комплекс заходів, орієнтованих на просування товару, різних послуги, бренду у внутрішньому або ж зовнішньому маркетинговому середовищі з метою організації спеціальних заходів. У свою чергу сьогодні це досить поширена сфера надання послуг із організації спеціальних заходів. Отримані події, які в рамках реалізації івентменеджменту є безпосередньо об'єктом управлінських зусиль, насамперед класифікуються за такими трьома типами: робочі заходи; відповідні інформативні заходи; заходи, що орієнтовані на організацію вільного часу [7; 8].

Івент-менеджмент сприймається безпосередньо в двох контекстах: як бізнес та як дієвий інструмент маркетингових комунікацій. Зміст такого явища полягає у тому, щоб подати конкретному споживачеві товари та послуги, як презент. Саме так, досить точно, можна передати цільовий зміст цього соціального, та за своєю природою й за спрямованістю впливу, економічного явища. Тобто, як перша, так й друга його характеристика $€$ досить актуальною у застосуванні до публічної сорери, адже говоримо не про прибуток, а безпосередньо про комунікацію, яка насамперед потребує витрат.

У зарубіжній та вітчизняній теорії відбувається використання одразу дох термінів - "івент-менеджмент" та "івент-маркетинг", що позначають різні, однак рівною мірою важливі складові в організації представлених спеціальних заходів. Акцентуємо увагу на розмежуванні даних понять, що $є$ свого роду базисом для розуміння концепції використання методів івент-менеджменту у сорері публічного управління.

Парадокс івент-маркетингу полягає у тому, що саме організаційні питання, характерні для менеджменту як такого, стають ключовими фракторами імідж-орормування події. Не секрет, що неврахування деталей під час організації заходу може призвести до встановлення у свідомості цільових аудиторій негативної асоціації та негативного досвідом у зв'язку з участю у цій події. I навпаки, увага до дрібниць сприяє створенню позитивної репутації навіть за умови недостатнього опрацювання стратегії в рамках загального маркетингу. Саме тому менеджмент і маркетинг у івенті так тісно взаємодіють між собою [8-9].

Додаткові труднощі при розмежуванні івент-маркетингу та івент-менеджменту виникають також у результаті двоякої сутності такого явища, адже це й бізнес, і різновид різних маркетингових комунікацій одночасно [9]. У свою чергу паралельно існують менеджмент івенткомпанії як організації, маркетингу послуг, події як певного інструменту маркетингу та організації події як відповідної сорери менеджменту, у тому числі для публічного управління. Ось чому, говорячи про івент-менеджмент у контексті публічного управління, необхідно уточнювати контекст висловлювання.

У процесі формування сучасного івент-менеджменту, як ефективного інструмента публічного управління, варто також представити й соціальні фактори. Вони лежать безпосередньо у площині сучасної культури, а тому й розглядати їх варто саме в рамках не лише управлінського, але й так званого соціологічного аналізу процесу споживання такого продукту для сучасної культури суспільством.

Також вважаємо, що у процесі налагодження впливу на споживача зі сторони суб'єктів івент-маркетингу спостерігається прояв так званого релаксу як однієї із технологічних функцій для сучасної культури. У нашому розумінні сприяння культури споживання продукту. Тобто $є$ релаксаційна практика, яка представлена на основі подієвої артикульованості й багатовимірної модальності.

Зазначимо, що в процесі реалізації спеціальних подій також спостерігаються всі ознаки й специфічні риси для індивідуальної тілесної релаксації, якою б спірною не була культурна детермінація такого типу, і колективної релаксації, яка порівнянна із соціокультурним потенціалом події та більш насиченою відповідними його формами. Безпосередньо подія та свято, на наш погляд, є саме тими культурними детермінантами та, свого роду, динамічними технологічними способами для формування релаксаційного ефекту, у контексті сприяння споживання суспільного продукту.

Отже, івент-менеджмент як певний соціальний феномен $є$ більш значимим управлінським та, у більшості маніпулятивним потенціалом, безпосередньо в аспекті критичної й творчої селекції для різних компонентів дотримання соціального досвіду, ніж безпосередньо звичайна рекламна діяльність або ж традиційний маркетинг. Такий лібералізуючий потенціал івент-події, на думку авторів, може актуалізуватися у різноманітних релаксаційних практиках на засадах споживання відповідного управлінського продукту або послуги.

\section{ВИСНОВКИ}

Враховуючи наведені нами аргументи, зробимо висновок щодо імплементації релаксаційного потенціалу спеціальних подій як дієвого інструменту сучасних івенттехнологій в публічному управлінні.

Така спеціальна івент-подія, як особливе неповсякденне явище для людського буття завжди має певну символічну основу, яка сприймається відповідними людьми як соціальна або ж надсоціальна цінність. Будучи по суті безпосереднім проявом шанування конкретної цінності, спеціальна подія потребує особливої регламентації у режимі дозвілля та вільного часу, а також у режимі так званої емоційної піднесеності, що є значним чинником для формування ії̈ релаксаційного еоректу.

Отриманий ефект за допомогою використання спеціальної події досягається двома абсолютно протилежними шляхами: по-перше, накопичене індивідуальне та соціальне напруження мінімізується під час події особливим характером різних толерантних та альтруїстичних комунікацій, які провокують у людей відчуття благополуччя, рівня безпеки й соціального комфрорту; подруге, зняття напруги може також досягатися шляхом усвідомленого тимчасового порушення представлених існуючих норм, які сорормувались у свідомості споживача та зазнають змін у ході практичного споживання культурного продукту. 
Варто також враховувати, що на конкретні системні способи практичної актуалізації реалізації релаксаційного потенціалу івент-менеджменту впливає зміст притаманною суспільству етнокультурної традиції щодо соціальної регламентації релаксаційних практик. Мабуть, що без урахування такої обставини неможливо представити чіткі концептуальні уявлення щодо організації специфіки і способів залучення конструктивного і деструктивного компонентів для релаксаційного потенціалу реалізації спеціальної події як дієвого інструменту просування товару або ж, як явища суспільного життя.

\section{Література:}

1. Event-менеджмент - организация мероприятий на высшем уровне URL: http://www.pr2b.net/ index.php/articles/91-listprevent.

2. Касьянов Ю.В. PR-кампания своими силами / Ю.В. Касьянов. Санкт-Петербург: Питер, 2008. 250 с.

3. Копылова Н. С чего начинается событие. Альманах лаборатория рекламы, маркетинга и Public Relation. 2004. № 5(36). URL: http://www.advlab.ru/articles/ article 340.htm.

4. Дьяченко Ю.В., Седікова І.А., Бондар В.А. Eventменеджмент як складник інформаційно-комунікаційних технологій у публічному управлінні. Вчені записки Таврійського національного університету імені В.І. Вернадського. Серія: Державне управління. 2020. Т. 31 (70). вип. № 6. С. 39-44.

5. Пашкевич М.Ю. Івент-технології у сорері дозвілля. Культурно-дозвіллєва діяльність у сучасному світі: кол. монографія. Київ: Вид-во: Ліра-К, 2017. 328 с.

6. Shone A. Successful event management: a practical handbook / A. Shone, B. Parry. Cengage Learning: EMEA, 2004. P. 13.

7. Tassiopoulos D. Event Management: A Professional and Developmental Approach / D. Tassiopoulos ed. Juta Pty Ltd, 2013. 510 p.

8. Tum J. Management of Event Operations / J. Tum, P. Norton, J. Nevan Wright. Oxford: Elsevier/ButterworthHeinemann, 2006. 280 p.

9. Gryshova I., Shabatura T., Nikoliuk O. Державне регулювання екотуризму в контексті Європейського досвіду. Наукові записки Інституту законодавства Верховної Ради України, 2020 (1), 126-136. Retrieved із https://instzak.com/index.php/journal/article/view/ 1783

10. Добрянська Н.А., Стоянова-Коваль С.С., Ніколюк О.В. Реалії сьогодення та перспективи розвитку туристичного бізнесу Одеської області. Економіка харчової промисловості. 2018. 10 (1), 9-15.

\section{References:}

1. PRTrade (2021), "Event-management - organization of events at the highest level", [online], available at: http://www.pr2b.net/index.php/articles/91listprevent (Accessed 10 March 2021).

2. Kas'yanov, Yu.V. (2008), PR-kampanija svoimi silami [PR campaign in the home], Piter, Sankt-Peterburg, Russia.

3. Kopylova, N. (2004), "PR campaign in the home", Al'manakh laboratoriya reklamy, marketinga i Public Relation, [online], vol, 5(36), available at: http://www. advlab.ru/articles/article340.htm (Accessed 10 March 2021).

4. Manikhi, A.A. (2010), "Event marketing: the concept, essence and benefits of event marketing", Rossiiskoe predprinimatel'stvo, vol, 3/1, pp. 69-73.

5. Pashkevich, M.Yu. (2017), "Event technology in the field of leisure", Kulturno-dozvillieva diialnist u suchasnomu sviti [Cultural and leisure activities in the modern world], Lyra-K, Kyiv, Ukraine.

6. Shone, A. and Parry, B. (2004), Successful event management: a practical handbook, Cengage Learning: EMEA, Andover, UK.

7. Tassiopoulos, D. (2013), Event Management: A Professional and Developmental Approach, Juta Pty Ltd, Claremont, South Africa.

8. Tum, J. Norton, P. and J. Wright, N. (2006), Management of Event Operations, Elsevier/ButterworthHeinemann, Oxford, UK.

9. Grishova, I. Yu. Shabatura, T.S. and Nikolyuk, O.V. (2020), "State regulation of ecotourism in the context of the European experience", Scientific Notes of the Institute of Legislation of the Verkhovna Rada of Ukraine, vol. (1), pp. 126-136. https://doi.org/10.32886/instzak.2020.01.13

10. Dobryanska, N.A. Stoyanova-Koval, S.S. and Nikolyuk, O.V. (2018), "Realities of the present and prospects of development of tourist business of Odessa region", Economics of the food industry, vol. 10 (1), pp. $9-15$.

Стаття надійшла до редакиї 18.03.2021 p. www. dy.nayka.com.ua

Електронне фахове видання

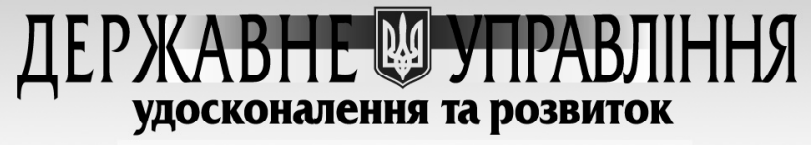

Виходить 12 разів на рік

включено до переліку наукових фахових видань України З ПИтань ДЕРЖАВНОГО УПРАВЛІННЯ

(Категорія «Б»)

Наказ Міністерства освіти і науки України від 28.12.2019 №1643

Спеціальність 281

e-mail:economy_2008@ukr.net

тел.: (044) 223-26-28, (044) 458-10-73 